AT - TADBIR

JURNAL ILMIAH MANAJEMEN

\title{
Pengaruh Budaya Organisasi, Motivasi Dan Lingkungan Kerja Terhadap Kinerja Mitra Dinas Koperasi Dan UKM
}

\author{
Seia Piantara, Sonny Hersona GW, Nelly Martini, Dede Jajang Suyaman \\ Fakultas Ekonomi dan Bisnis, Universitas Singaperbangsa Karawang \\ Jl. H.S Ronggowaluyo Telukjambe Timur, Karawang, Jawa Barat 41361 \\ e-mail: seia.piantara23@gmail.com
}

\begin{abstract}
This study aims to analyze and obtain findings of factual conditions of organizational culture, motivation, work environment and performance of partners. This research was conducted on the Partners of the Department of Cooperatives and SMEs in Karawang Regency in. This research is descriptive and verification with a quantitative approach. The data analysis method used is descriptive analysis and path analysis. The population of all Karawang Regency Cooperatives and SMEs Service Partners in 2019 found 207 people and the research sample found 136 people. The results showed that organizational culture with work motivation had a very low level of correlation and a positive value, the correlation between motivation and the work environment was very low and a positive value and the correlation between organizational culture and the work environment had a low level of relationship and a positive value. The results that have been carried out show that the performance of the Karawang Regency Cooperatives and SMEs Service Partners in 2019 is influenced by organizational culture, motivation and work analysis by $39.63 \%$ while the remaining $60.37 \%$ is influenced by other factors. Where the variable that has the greatest direct influence is organizational culture on performance of $20.42 \%$, followed by work environment of $13.14 \%$ and motivation on performance of $6.08 \%$.
\end{abstract}

Keywords: organizational culture, motivation, work environment, partner performance

\begin{abstract}
Abstrak
Penelitian ini bertujuan untuk menganalisis dan memperoleh temuan kondisi faktual budaya organisasi, motivasi, lingkungan kerja dan kinerja para mitra. Penelitian ini dilakukan terhadap Mitra Dinas Koperasi dan UKM Kabupaten Karawang tahun. Penelitian ini bersifat deskriptif dan verifikatif dengan pendeatan kuantitatif. Metode analisis data yang digunakan adalah analisis deskriptif dan analisis jalur. Populasi seluruh Mitra Dinas Koperasi dan UKM Kabupaten Karawang tahun 2019 berjumlah 207 orang dan sampel penelitian berjumlah 136 orang. Hasil penelitian mununjukan bahwa budaya organisasi dengan motivasi kerja memiliki tingkat korelasi yang sangat rendah dan nilainya positif, korelasi antara motivasi dengan lingkungan kerja memiliki tingkat hubungan sangat rendah dan nilainya positif dan korelasi antara budaya organisasi dengan lingkungan kerja memiliki tingkat hubungan rendah dan nilainya positif. Hasil analisis yang telah dilakukan diperoleh kesimpulan bahwa kinerja Mitra Dinas Koperasi dan UKM Kabupaten Karawang tahun 2019 dipengaruhi secara positif oleh budaya organisasi, motivasi dan lingkungan kerja sebesar 39,63\% sedangkan sisanya sebesar $60,37 \%$ dipengaruhi oleh faktor lain. Dimana variabel yang memiliki pengaruh langsung terbesar yaitu budaya organisasi terhadap kinerja sebesar 20,42\%, diikuti lingkungan kerja terhadap kinerja sebesar 13,14\% dan motivasi terhadap kinerja sebesar 6,08\%.
\end{abstract}

Kata kunci: Budaya organisasi, Motivasi, Lingkungan Kerja, Kinerja mitra 


\section{PENDAHULUAN}

Sumber Daya Manusia dalam organisasi harus memiliki kinejra baika yang senantiasa berorientasi terhadap visi, misi, tujuan dan sasaran organisasi. Untuk itu diperlukan sumber daya manusia yang berkualitas, sebagai upaya dalam meningkatkan kualitas Sumber Daya Manusia diperlukan pendidikan yang baik, serta adanya fasilitas sosial yang mendukung lainnya. Instansi pemerintah merupakan salah satu bentuk organisasi non profit yang bertujuan untuk meningkatkan pelayanan kepada masyarakat umum, seperti peningkatan keamanan, peningkatan mutu pendidikan atau peningkatan mutu kesehatan dan lain-lain. Salah satu tantangan besar organisasi pemerintahan saat ini adalah melaksanakan kinerja secara efektif dan efesien karena selama ini instansi pemerintahan diidentikkan dengan kinerja yang lambat, rumit, berbelit-belit dan penuh dengan Korupsi, Kolusi dan Nepotisme (Jamaluddin et al., 2017). Fachreza et al. (2018) menyebutkan kinerja atau performance adalah hasil kerja yang dapat dicapai oleh seorang atau sekelompok orang dalam suatu organisasi, sesuai dengan tanggung jawab dan wewenang masing-masing dalam upaya mencapai tujuan organisasi. Peningkatan kinerja pegawai pada organisasi publik secara teoritis maupun empiris dapat dipengaruhi oleh beberapa faktor, seperti faktor budaya organisasi, motivasi kerja, dan lingkungan kerja.

Budaya organisasi dapat membantu kinerja pegawai, karena menciptakan suatu tingkat motivasi yang luar biasa bagi pegawai untuk memberikan kemampuan terbaiknya dalam memanfaatkan kesempatan yang diberikan oleh organisasinya. Menurut penelitian (Ahmed \& Shafiq, 2014), budaya organisasi merupakan sebagai kombinasi dari nilai-nilai, aset, keyakinan, komunikasi dan penyederhanaan perilaku yang memberikan arahan kepada masyarakat. Ide dasar budaya muncul melalui berbagi proses pembelajaran yang didasarkan pada alokasi sumber daya yang tepat. Menurut penelitian Chang dan Lee (dalam Asmawati., 2019) setiap orang ditampilkan dengan berbagai karakteristik dan gaya perilaku, berbagai organisasi bisnis juga datang dengan budaya warisan mereka untuk mempengaruhi operasi organisasi. Jika setiap individu memahami budaya organisasi dengan benar, maka kinerja organisasi akan meningkat serta pegawai akan merasa termotivasi dalam melaksankan pekerjaan organisasinya.

Motivasi kerja merupakan salah satu faktor yang menentukan peningkatan kinerja pegawai. Dengan motivasi kerja yang tinggi, karyawan akan bekerja lebih giat di dalam melaksanakan pekerjaannya. Motivasi adalah suatu keadaan dalam pribadi yang mendorong keinginan individu untuk melakukan keinginan tertentu guna mencapai tujuan (Fachreza et al.,2018) Menurut hasil penelitian yang dilakukan oleh (Supriyanto \& Mukzam, 2018), menunjukan bahwa motivasi kerja mampu mempengaruhi kinerja karyawan, dimana jika motivasi kerja meningkat maka kinerja yang didapat akan semakin meningkat, begitu pula sebaliknya.

Selain faktor motivasi kerja, lingkungan kerja tempat karyawan tersebut bekerja juga tidak kalah pentingnya di dalam meningkatkan kinerja karyawan. Lingkungan kerja merupakan suatu tempat yang terdapat sejumlah kelompok dimana di dalamnya terdapat beberapa fasilitas pendukung untuk mencapai tujuan perusahaan sesuai dengan visi dan misi perusahaan. Menurut penelitian (Sarwani, 2016), jika perusahaan ingin meningkatkan kinerja karyawan melalui lingkungan kerja, maka yang perlu diperhatikan adalah menyediakan lingkungan kerja yang mendukung terciptanya suasana kerja yang harmonis dan dinamis yang 
diharapkan dapat meningkatkan kinerja karyawan.

Dinas Koperasi dan UKM Kabupaten Karawang, merupakan salah satu instansi pemerintah yang memiliki tanggung jawab tentang semua yang berkaitan koperasi dan pelaku Usaha Mikro Kecil dan Menengah (UMKM). Visi Dinas Koperasi dan Usaha Kecil Menengah (DINKOPUKM) yaitu "Terwujudnya Koperasi dan Usaha Mikro Yang Tangguh dan Mandiri”, dengan visi seperti itu dibutuhkan sumber daya manusia yang siap untuk mewujudkannya. Meskipun Dinas Koperasi dan UKM Kabupaten Karawang memiliki 207 orang mitra yang berfungsi sebagai kepanjangan tangan DINKOPUKM dalam pelaksanaan program atau kegiatan. Dimana 10 oarang atau $4.67 \%$ adalah pendamping UMKM (ABDSI), 70 orang atau $46.73 \%$ berasal dari AKUM, 55 orang atau $11.68 \%$ adalah dari Komunitas Sahabat UKM (SU), 37 orang atau $17.29 \%$ dari Koperasi Produsen Sangga Buana Karawang (KPSB) dan 35 orang atau $16.36 \%$ berasal dari Komunitas ABCGM (Akademisi, Bisnis, Perusahaan, Pemerintah dan Media) namun belum bisa menjamin terlaksananya capaian kinerja dengan baik. Berdasarkan data Dinas Koperasi dan UKM Kabupaten Karawang tahun 2019, bahwa capaian kinerja mitra DINKOPUKM pada tahun 2019 sebesar $67.5 \%$, artinya sebesar $32.5 \%$ kegiatan mitra tidak tercapai. Jika tidak dilakukan perbaikan, maka visi untuk mewujudkan Koperasi dan pelaku Usaha Mikro Yang tangguh dan mandiri jelas tidak akan tercapai. Sebagai upaya untuk mampu meningkatkatkan kinerja dengan kondisi tersebut diantaranya dengan meningkatkan pemahaman terhadap budaya organisasi, memberikan motivasi kerja dan memperbaiki lingkungan kerja.

Berdasarkan dari penjelasan tersebut, penelitian ini bertujuan untuk mengetahui tata Kelola organisasi mitra dinas koperasi dan UMKM kab karawang yang diukur melalui tingkat budaya organisasi, motivasi dan lingkungan kerja.

\section{KAJIAN PUSTAKA}

Budaya Organisasi

Budaya organisasi merupakan suatu kekuatan sosial yang tidak tampak, yang dapat menggerakkan orang-orang dalam suatu organisasi untuk melakukan aktivitas kerja. Menurut Ivancevich, et al. (dalam Joushan, 2015) budaya organisasi adalah sistem nilai, keyakinan, norma yang meresap yang ada di organisasi.

Budaya organisasi memberikan perspektif teoretis yang berpusat pada orang tentang manajemen perubahan yang dipandang menawarkan beberapa wawasan tentang sifat "tidak berwujud" organisasi dan perilaku mereka: pendekatan yang kontras dengan pandangan manajemen tradisional organisasi (struktur formal, aturan dan prosedur dan argumen rasional).

Pemeriksaan budaya organisasi memunculkan isu-isu filosofis yang penting dan tidak dapat dihindari sebelum mengusulkan kerangka kerja atau kerangka acuan (Maul et al., 2001). Ada dua bidang utama di mana isu-isu filosofis harus ditangani, yaitu perspektif teoretis budaya organisasi dan pendekatan penelitian budaya organisasi. Mereka hanya dinyatakan sebagai 1 . Apakah budaya organisasi merupakan variabel independen atau dependen (internal) (yaitu apakah budaya organisasi merupakan sesuatu yang dimiliki atau dimiliki oleh suatu organisasi?). 2. Landasan epistemologis metode penelitian yang memengaruhi alat, metode, dan intervensi yang dimiliki pengguna. 


\section{Motivasi Kerja}

Motivasi kerja merupakan proses yang menghasilkan suatu intensitas, arah dan ketekunan individu dalam usaha untuk mencapai suatu tujuan. Kunci dalam motivasi kerja ialah ketiga unsur hasil dari proses motivasi kerja yang difokuskan. Menurut Hasibuan (2015), motivasi adalah pemberian daya penggerakan yang menciptakan kegairahan kerja seseorang agar mereka mau bekerja sama, pekerja efektif dan terintegrasi dengan segala daya upayanya untuk mencapai kepuasan. Sedangkan McClelland (dalam Hamali, 2018) menyebutkan seseorang akan termotivasi jika ketiga kebutuhannya terpenuhi yaitu kebutuhan berprestasi, kebutuhan berafiliasi, kebutuhan berkuasa.

Oleh karena itu, persepsi kerja juga dibedakan menurut sikap terhadap pekerjaan itu sendiri (Czerw, 2013)-autotelik atau instrumental. Dalam kasus sikap autotelik, pekerjaan dianggap sebagai nilai dalam dirinya sendiri dan sumber pengembangan pribadi; itu adalah cara hidup dan secara signifikan terkait dengan pemenuhan diri (Makuch, 2014). Sikap instrumental terdiri dari memperlakukan pekerjaan hanya sebagai kondisi memuaskan kebutuhan dasar individu: sarana mendukung diri sendiri, memenuhi kebutuhan keamanan, dan memenuhi kebutuhan lain di luar lingkungan kerja. Ini berarti pekerjaan adalah instrumen yang melayani tujuan memperoleh sumber daya keuangan, yang dapat digunakan dalam domain penting lainnya dari kehidupan individu.

Motivasi untuk bekerja telah berubah selama bertahun-tahun; pada tahun 1940-an, apa yang paling dihargai karyawan adalah pengakuan yang mereka terima atas pekerjaan yang dilakukan, sedangkan faktor yang paling tidak memotivasi mereka adalah disiplin (Peplińska et al., 2018). Pada tahun 1980-an karyawan dimotivasi oleh kesempatan untuk melakukan pekerjaan yang menarik, dan pada tahun 1990-anoleh upah yang tinggi. Elemen-elemen yang memotivasi karyawan untuk bekerja seringkali adalah elemen-elemen yang konsisten dengan sistem nilai mereka (Peplińska et al., 2018).

\section{Lingkungan Kerja}

Lingkungan kerja adalah tempat dimana karyawan melakukan aktivitas setiap harinya. menurut Sedarmayanti (2013) menyatakan bahwa lingkungan kerja adalah keseluruhan alat perkakas dan bahan yang dihadapi, lingkungan sekitarnya dimana seseorang bekerja, metode kerjanya, serta pengaturan kerjanya baik sebagai perseorangan maupun sebagai kelompok. Lingkungan kerja yang kondusif memberikan rasa aman dan memungkinkan para pegawai untuk dapat bekerja optimal. Pada umumnya lingkungan tidak dapat dikendalikan oleh perusahaan sehingga perusahaan harus menyesuaikan diri dengan lingkungan. Dengan memperhatikan lingkungan kerja yang baik atau menciptakan kondisi kerja yang dapat memberikan motivasi untuk bekerja (Sofyan, 2013).

Lingkungan kerja ini terdiri dari lingkungan kerja fisik dan non fisik yang melekat pada karyawan yang tidak dapat dipisahkan dari usaha pengembangan kinerja karyawan (Bushiri, 2014). Dimensi lingkungan kerja menurut Sedarmayanti (2013), terbagi menjadi lingkungan kerja fisik dan non fisik.

\section{Kinerja}

Kinerja merupakan perilaku organisasi yang secara langsung berhubungan dengan produksi barang atau penyampaian jasa. Menurut Kasmir (2016;182) kinerja adalah 
hasil kerja dan perilaku kerja yang telah dicapai dalam menyelesaikan tugas-tugas dan tanggung jawab yang diberikan dalam suatu periode tertentu.

Kinerja dipengaruhi oleh variabel yang berhubungan dengan pekerjaan meliputi stres konflik peran dan pekerjaan/non pekerjaan (Riyanto, 2002; Jayaweera, 2015). Kinerja seseorang merupakan kombinasi dari kemampuan, usaha dan peluang yang dapat dinilai dari pekerjaannya (Handayani, 2015). Kinerja individu dipengaruhi oleh usaha, kemampuan dan situasi lingkungan (Riyanto, 2016).

Pemahaman lain mengenai kinerja diungkapkan oleh Riyanto et al. (2017) menyatakan bahwa kinerja adalah suatu hasil yang dicapai seseorang di bawah ukuran yang berlaku pada pekerjaan yang bersangkutan. Setyo et al (2017) menyatakan bahwa kinerja adalah catatan hasil yang dihasilkan dari fungsi atau aktivitas karyawan tertentu yang dilakukan selama periode waktu tertentu. Kinerja keseluruhan suatu jabatan sama dengan jumlah (rata-rata) kinerja fungsi atau aktivitas yang dilakukan pegawai.

Menurut Mangkunegara (2011. p. 67) dimensi kinerja pegawai dibagi menjadi lima, yaitu kualitas kerja, kuantitas kerja, tanggung jawab, kerjasama dan inisiatif.

\section{METODE PENELITIAN}

\section{Jenis Penelitian}

Metode penelitian yang digunakan dalam penelitian ini adalah melalui pendekatan kuantitatif dengan analisis deskriptif dan verifikatif.

\section{Lokasi dan Waktu Penelitian}

Objek penelitian yaitu Dinas Koperasi dan UKM Kabupaten Karawang dengan unit penelitian para mitra Dinas Koperasi dan UKM Kabupaten Karawang.

\section{Populasi dan Sampel}

Populasi dalam penelitian ini adalah seluruh mitra Dinas Koperasi dan UKM Kabupaten Karawang sebanyak 207 orang sedangkan jumlah sampel berjumlah 136 orang yang diangap mampu mewakili populasi yang ada.Teknik penarikan sampel menggunakan simple random sampling, menurut Siregar (2012) simple random sampling merupakan teknik pengambilan sampel yang memberikan kesempatan yang sama kepada setiap anggota yang ada dalam suatu populasi untuk dijadikan sampel

\section{Pengumpulan data}

Teknik pengumpulan data melalui penelitian lapangan dan kepustakaan berdasarkan data yang digunakan yaitu melakukan observasi awal yang dilakukan pada tanggal 22 Maret dan 30 April 2020. Observasi dilakukan dengan mengamati mitra Dinas Koperasi dan UKM Kabupaten Karawang, kemudian melakukan wawancara mengenai fenomena di Dinas Koperasi dan UKM Kabupaten Karawang dilakukan kepada Bagian Divisi kepegawaian dan beberapa beberapa mitra di Dinas Koperasi dan UKM Kabupaten Karawang, penyebaran kuesioner serta data yang diambil secara tidak langsung yang merupakan data yang telah diolah yaitu berbagai referensi buku, makalah, materi perkuliahan yang berhubungan dengan objek data baik yang akan diteliti oleh penulis.

\section{Teknik Analisis Data}

Teknik analisis data menggunakan rancangan analisis deskriptif dan verifikatif. Analisis deskriptif digunakan untuk mendeskripsikan atau menggambarkan data yang telah terkumpul sebagaimana adanya tanpa bermaksud membuat kesimpulan yang berlaku untuk umum atau generalisasi (Sugiyono, 2017). Analisis Deskriptif yang 
digunakan yaitu analisis tabulasi data dan grafik serta analisis rentang skala.

Sebagai persyaratan pengujian regresi linear berganda, maka dilakukan pengujian asumsi normalitas yang ditunjukkan pada tabel 1. Berdasarkan dari tabel di atas terlihat bahwa semua indikator dari ke empat variabel tersebut berdistribusi normal karena nilai Kolmogorov-Smirnov > 0,05. Dengan demikian data dapat dianalisis pada analisis verifikatif.

Analisis verifikatif pada penelitian ini mengunakan beberpa pengujian diantaranya adalah analisis korelasi produk moment (correlation product moment) dan analisis jalur. Model path analysis yang dibicarakan adalah pola hubungan sebab akibat. Adapun rancangan analisis untuk penelitian ini dapat dilihat pada gambar berikut ini:

Dengan persamaan analisis jalur, sebagai berikut $\mathrm{Y}=\rho y x_{1} \mathrm{X}_{1}+\rho y x_{2} \mathrm{X}_{2}+\rho y x_{3} \mathrm{X}_{3}+$ $\rho y \varepsilon$. Dan analisis data terakhir adalah Koefisien determinasi. Koefisien determinasi dilambangkan $\mathrm{R}^{2}$ merupakan proporsi hubungan antara $\mathrm{Y}$ dan $\mathrm{X}$. Nilai koefisien determinasi adalah diantara 0 (nol) dan 1 (satu).

Tabel 1. Hasil Uji Normalitas Data Variabel Penelitian

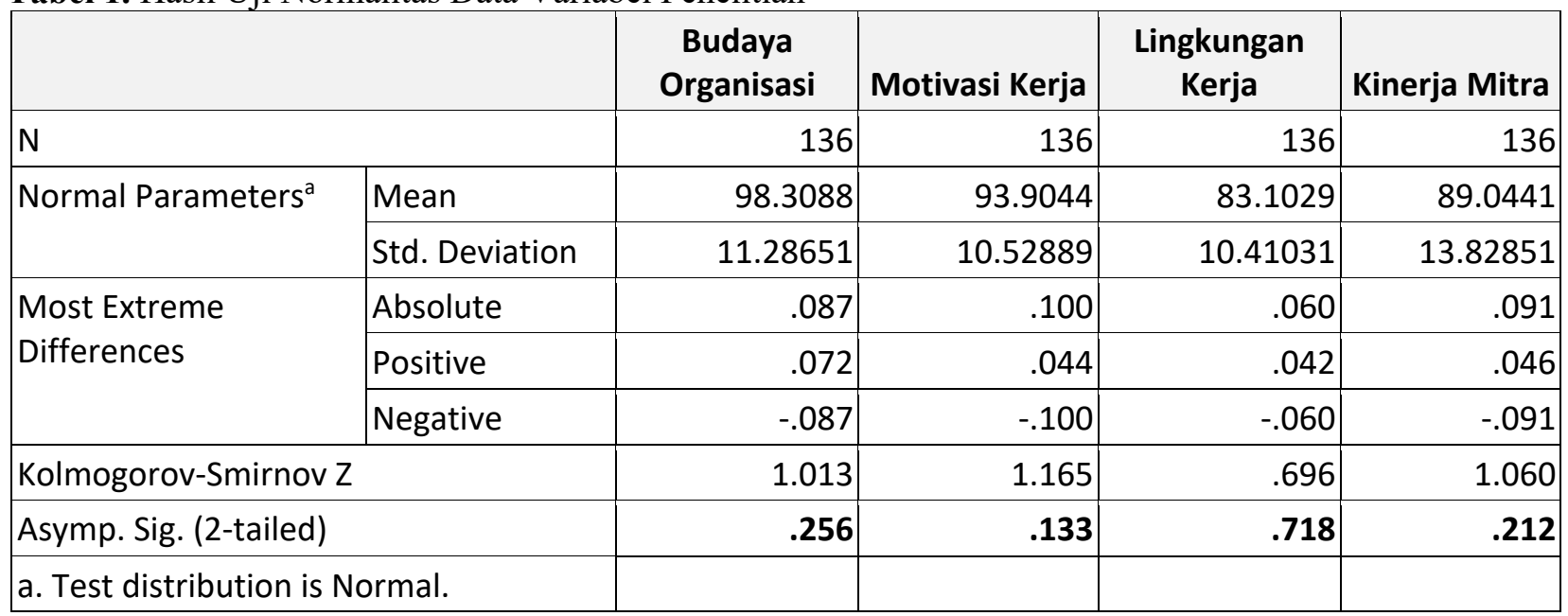

Sumber: Data Diolah, 2020

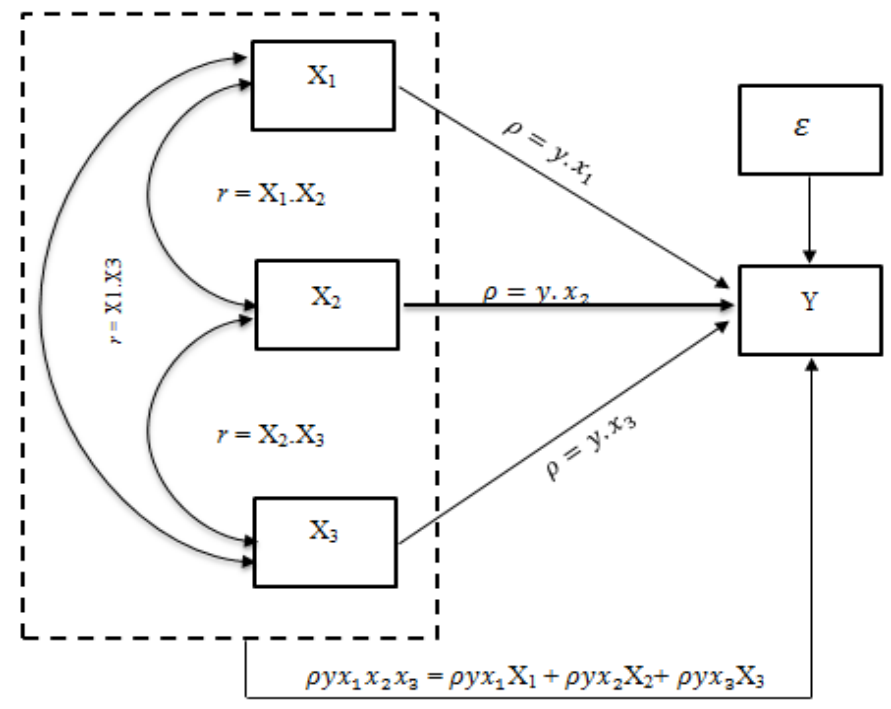

Keterangan:

X1 : Budaya Organisasi;

X2 : Motivasi Kerja;

X3 : Lingkungan Kerja;

Y : Kinerja Mitra

Gambar 1. Model Konseptual Penelitian

Sumber: Data diolah 2021 
HASIL DAN PEMBAHASAN

Hasil

\section{Analisis Statistik deskriptif}

Dalam penelitian ini statistik deskriptif dilihat dari nilai minimum, nilai maksimum, nilai rata-rata (mean) dan standar deviasi.

Berdasarkan tabel 2 diketahui bahwa budaya organisasi berada pada kategori jawab setuju dengan nilai skor rata-rata sebesar 471,1. Hal ini menunjukan bahwa budaya organisasi mitra Dinas Koperasi dan UKM Kabupaten Karawang sudah baik. Motivasi kerja berada pada katagori jawaban cukup baik. Hal ini menunjukan bahwa motivasi kerja mitra Dinas Koperasi dan UKM Kabupaten Karawang saat ini cukup baik. Lingungan kerja berada pada rentang skala cukup baik. Hal ini menunjukan bahwa lingkungan kerja mitra
Dinas Koperasi dan UKM Kabupaten Karawang saat ini kondisinya cukup baik. Kinerja berada pada kategori jawaban cukup baik. Hal ini menunjukan bahwa kinerja mitra Dinas Koperasi dan UKM Kabupaten Karawang saat ini kondisinya cukup baik.

\section{Uji Verifikasi}

Seperti yang telah disebutkan di atas, uji verifikasi dilakukan melalui uji korelasi dan pengujian model. Pada Tabel 3 diperoleh besaran nilai koefesien korelasi antara budaya organisasi dengan motivasi sebesar 0,165 ; besaran nilai koefesien korelasi antara motivasi dengan lingkungan kerja sebesar 0,223; besaran nilai koefesien korelasi antara budaya budaya organisasi dengan lingkungan kerja sebesar 0,368.

Tabel 2. Hasil Analisis Deskriptif Variabel Penelitian

\begin{tabular}{|c|l|c|c|}
\hline No & \multicolumn{1}{|c|}{ Variabel } & Nilai Skor Rata-rata & Kategori \\
\hline 1 & Budaya Organisasi & 471,1 & Setuju \\
\hline 2 & Motivasi Kerja & 461 & Cukup Baik \\
\hline 3 & Lingkungan Kerja & 424,9 & Cukup Baik \\
\hline 4 & Kinerja & 438,8 & Cukup Baik \\
\hline
\end{tabular}

Sumber: Data Diolah, 2020

Tabel 3. Korelasi Variabel Penelitian

\begin{tabular}{|l|c|c|}
\hline \multicolumn{1}{|c|}{ Hubungan } & Korelasi Pearson & Sig. \\
\hline Budaya Organisasi - Kinerja & 0,165 & 0,000 \\
\hline Motivasi Kerja - Kinerja & 0,223 & 0,000 \\
\hline Lingkungan kerja - Kinerja & 0,368 & 0,000 \\
\hline
\end{tabular}

Sumber Data diolah, 2020

Tabel 4. Nilai Koefesien Jalur

\begin{tabular}{|c|c|c|c|c|c|c|}
\hline \multirow{2}{*}{\multicolumn{2}{|c|}{ Model }} & \multicolumn{2}{|c|}{$\begin{array}{l}\text { Unstandardized } \\
\text { Coefficients }\end{array}$} & \multirow{2}{*}{\begin{tabular}{|c|}
$\begin{array}{c}\text { Standardized } \\
\text { Coefficients }\end{array}$ \\
Beta \\
\end{tabular}} & \multirow[b]{2}{*}{$\mathbf{t}$} & \multirow[b]{2}{*}{ Sig. } \\
\hline & & B & Std. Error & & & \\
\hline \multirow[t]{4}{*}{1} & (Constant) & -14.810 & 11.747 & & -1.261 & .210 \\
\hline & Budaya Organisasi & .473 & .089 & .386 & 5.326 & .000 \\
\hline & Motivasi Kerja & .257 & .091 & .195 & 2.824 & .005 \\
\hline & Lingkungan Kerja & .400 & .099 & .301 & 4.053 & .000 \\
\hline
\end{tabular}

a. Dependent Variable: Kinerja

Sumber Data diolah, 2020 


\section{Pengujian Model dan Hipotesis}

Berdasarkan tabel 4 diketahui bahwa besaran derajat asosiatif atau koefisien jalur variabel budaya organisasi $(0,386)$ lebih tinggi dibandingkan kedua variabel lain yaitu lingkungan kerja $(0,301)$ dan motivasi $(0,195)$, artinya budaya organisasi memiliki nilai koefesien jalur tinggi terhadap kinerja. Adapun persamaan jalurnya sebagai berikut :

$\mathrm{Y}=\left(0,386 \mathrm{X}_{1}\right)+0,195 \mathrm{X}_{2}+\left(0,301 \mathrm{X}_{3}\right)+\varepsilon$

\section{Pembahasan}

\section{Korelasi Antara Budaya Organisasi Dengan Motivasi Kerja Mitra Dinas Koperasi Dan UKM}

Berdasarkan hasil analisis, diperoleh besaran nilai koefesien korelasi antara budaya organisasi dengan motivasi sebesar 0,165 . Dengan demikian korelasi budaya organisasi dengan motivasi memiliki tingkat hubungan sangat rendah dan nilainya positif dikarenakan berada di interval koefisien nilai 0,10 sampai 0,299 yang berarti sangat rendah (Sugiyono, 2013:184). Dan berdasarkan hasil uji hipotesis diperoleh ttabel $=1,656$. Dengan demikian diketahui thitung $(1,937)>$ ttabel $(1,6568)$, maka dapat dinyatakan bahwa Hoditolak, artinya ada hubungan yang signifikan antara budaya organisasi dengan motivasi. Kondisi ini menunjukan bahwa budaya organisasi mampu memberikan pengaruh secara langsung pada terciptanya dorongan dalam diri karyawan. Hasil penelitian yang relevan dengan hal tersebut dilakukan oleh (Christina, 2014), serta didukung oleh hasil penelitian (Sagita et al., 2018), dimana hasilnya menunjukan bahwa penerapan budaya organisasi yang baik akan secara positif dan signifikan meningkatkan motivasi kerja karyawan, begitu pula sebaiknya budaya organisasiyang kurang baik akan secara negatif dan signifikan menurunkan motivasi kerja karyawan.

\section{Korelasi Antara Motivasi Dengan Lingkungan Kerja Mitra Dinas Koperasi Dan UKM}

Berdasarkan hasil analisis, diperoleh besaran nilai koefesien korelasi antara motivasi dengan lingkungan kerja sebesar 0,223 . Dengan demikian motivasi dengan lingkungan kerja memiliki tingkat korelasi sangat rendah dan searah nilainya positif dikarenakan berada di interval koefisien nilai 0,10 sampai 0,299 (sugiyono, 2013:184). Dan berdasarkan hasil uji hipotesis diperoleh ttabel $=1,656$. Dengan demikian diketahui thitung $(2,648)>$ ttabel $(1,6568)$, maka dapat dinyatakan bahwa Hoditolak, artinya ada hubungan yang signifikan antara motivasi dengan lingkungan kerja. Kondisi ini menunjukan bahwa motivasi kerja mitra akan meningkat jika kondisi lingkungan kerja baik dan konsdusif. Hasil penelitian yang relevan dilakukan oleh (Supriyanto \& Mukzam, 2018) dan (Rico Dio Alfonso, 2018), dimana hasil penelitiannya menunjukan bahwa motivasi kerja, lingkungan kerja mempunyai korelasi yang positif dan signifikan terhadap kinerja pegawai.

\section{Korelasi Antara Budaya Organisasi Dengan Lingkungan Kerja Mitra Dinas Koperasi Dan UKM}

Berdasarkan hasil analisis, diperoleh besaran nilai koefesien korelasi antara budaya budaya organisasi dengan lingkungan kerja sebesar 0,368. Dengan demikian budaya organisasi dengan lingkungan kerja memiliki tingkat korelasi yang rendah dan searah nilainya positif dikarenakan berada di interval koefisien nilai 0,20 sampai 0,399 (sugiyono, 2013:184). Dan berdasarkan hasil uji hipotesis diperoleh ttabel $=1,656$. Dengan demikian diketahui thitung $(4,581)>$ ttabel $(1,6568)$, maka dapat dinyatakan bahwa Hoditolak, artinya ada hubungan yang signifikan antara budaya organisasi dengan 
lingkungan kerja. Kondisi ini menunjukan bahwa budaya organisasi akan baik jika ditunjang dengan kondisi lingkungan kerja yang baik pula, begitu sebaliknya. Penelitian relevan dilakukan oleh (Hamdani, 2017) dan (Asmawati, 2019), dimana hasilnya menunjukan bahwa budaya organisasi dengan lingkungan kerja memiliki hubungan yang positif menaningkatkan kinerja pegawai.

\section{Pengaruh Budaya Organisasi Terhadap Kinerja Mitra Dinas Koperasi Dan UKM}

Hasil penelitian menunjukan bahwa budaya organisasi berpengaruh positif signifikan terhadap kinerja mitra Dinas Koperasi dan UKM Kabupaten Karawang sebesar 20,42\%. Kondisi ini menunjukan bahwa semakin baik budaya organisasi maka akan meningkatkan kinerja mitra Dinas Koperasi dan UKM. Hasil ini didukung oleh hasil penelitian yang dilakukan (Stephen \& Stephen, 2016), (Ahmed \& Shafiq, 2014), (Wambugu, 2014), Chang dan Lee (2007), dan Salihu, et al (2016), dapat disimpulkan bahwa budaya organisasi memiliki peran penting dalam mencapai tujuan organisasi dan dapat meningkatkan kinerja pegawai.

\section{Pengaruh Motivasi Terhadap Kinerja Mitra Dinas Koperasi Dan UKM}

Hasil penelitian menunjukan bahwa motivasi berpengaruh positif signifikan terhadap kinerja mitra Dinas Koperasi dan UKM Kabupaten Karawang sebesar 6,08\%. Kondisi ini menunjukan bahwa jika motivasi kerja mitra dapat ditingkatkan, maka akan mampu meningkatkan kinerja mitra Dinas Koperasi dan UKM Kabupaten Karawang. Peningkatan motivasi kerja pegawai akan memberikan peningkatan yang sangat berarti bagi peningkatan kinerja pegawai dalam melaksanakan pekerjaanya, oleh karena itu motivasi kerja yang tinggi sangat diperlukan organisasi untuk meningkatkan kinerja pegawainya. Peningkatan motivasi kerja akan mendorong prestasi kinerja karyawan meningkat (Rivai, 2014). Menurut penelitian (Riyanto, Sutrisno, dan Ali, 2017), (Hamdani, 2017), (Bi-cho, Dias, Leite, \& Ramires, 2017), dimana hasil penelitiannya menunjukan bahwa motivasi kerja adalah variabel yang paling berpengaruh dalam menjelaskan variabel kinerja pegawai. Serta didukung oleh hasil penelitian (Supriyanto \& Mukzam, 2018). Semakin tinggi motivasi dan kemampuan maka semakin tinggi kinerja karyawan terse-but, begitu juga sebaliknya (Mangkunegara, 2013).

\section{Pengaruh Lingkungan Kerja Terhadap Kinerja Mitra Dinas Koperasi Dan UKM}

Hasil penelitian menunjukan bahwa lingkungan kerja berpengaruh positif signifikan terhadap kinerja mitra Dinas Koperasi dan UKM Kabupaten Karawang sebesar 13,14\%. Kondisi ini menunjukan bahwa semakin baik lingkungan kerja, semakin baik pula kinerja yang ditunjukkan oleh karyawan. Lingkungan kerja di dalam suatu instansi penting untuk diperhatikan, dengan adanya lingkungan kerja yang memadai tentunya akan membuat karyawan betah bekerja, sehingga akan timbul semangat kerja dan kegairahan kerja karyawan dalam melaksanakan pekerjannya sehingga kinerja karyawan akan meningkat. Hasil ini didukung oleh penelitian yang dilakukan (Palvalin, 2017), (Lestary \& Harmon, 2018), Menurut penelitian (Sarwani, 2016), jika perusahaan ingin meningkatkan kinerja karyawan melalui lingkungan kerja, maka yang perlu diperhatikan adalah menyediakan lingkungan kerja yang mendukung terciptanya suasana kerja yang harmonis dan dinamis yang diharapkan dapat meningkatkan kinerja karyawan. 
Pengaruh Budaya Organisasi, Motivasi dan Lingkungan Kerja Terhadap Kinerja Mitra Dinas Koperasi Dan UKM

Hasil penelitian meunjukan bahwa pengaruh secara simultan variabel budaya organisasi, motivasi dan lingkungan kerja terhadap kinerja sebesar 0,3963 atau 39,63\% sedangkan sisanya sebesar $60,37 \%$ dipegaruhi oleh faktor lain. Hasil penelitian ini sesuai dengan hasil penelitian (Fachreza et al., 2018) dan (Hamdani, 2017), dimana hasilnya menunjukan bahwa motivasi kerja, lingkungan kerja, dan budaya organisasi baik secara parsial maupun secara simultan berpengaruh signifikan dan positif terhadap kinerja karyawan. Seorang karyawan yang memiliki kinerja yang baik dapat menunjang tercapainya tujuan dan sasaran yang telah ditetapkan oleh perusahaan. Menurut Kiruja dan Elegwa (Kiruja, 2013) kinerja karyawan merupakan fungsi dari kemampuan dan motivasi, di mana kemampuan terdiri dari keterampilan, pelatihan dan sumber daya yang diperlukan untuk melakukan tugas dan motivasi digambarkan sebagai kekuatan batin yang mendorong individu untuk bertindak terhadap sesuatu Flippo (2001) menambahkan bahwa kinerja karyawan dalam institusi/ lembaga lebih termotivasi adalah yang memiliki dorongan untuk meningkatkan produktivitas, kualitas, kuantitas, dan komitmen. Bagi Dinas Koperasi dan UKM Kabupaten Karawang, budaya yang diterapkan dalam organisasi sangat penting karena budaya organisasi tersebut yang akan mempengaruhi dan memberikan pedoman bagi anggota organisasi untuk melaksanakan pekerjaanya.

\section{KESIMPULAN DAN SARAN}

Kesimpulan

Dari penelitian yang telah dilakukan ditemukan beberapa fakto yang mampu meningkatkan kinerja organisasi. Korelasi budaya organisasi dengan motivasi kerja memiliki tingkat korelasi yang sangat rendah dan nilainya positif artinya bila terjadi perbaikan budaya organisasi akan berkorelasi posistif terhadap peningkatan motivasi kerja, Korelasi antara motivasi dengan lingkungan kerja memiliki tingkat hubungan sangat rendah dan nilainya positif artinya setiap terjadi perubahan peningkakatan/penurunan motivasi kerja akan berkorelasi positif terhada situasi lingkungan kerja. Korelasi antara budaya organisasi dengan lingkungan kerja memiliki tingkat hubungan rendah dan nilainya positif yang berarti bahwa setiap terjadi perubahan budaya organisasi akan berkorelasi positif terhadap kondisi lingkungan kerja. Budaya organisasi secara parsial berpengaruh signifikan terhadap kinerja mitra Dinas Koperasi dan UKM Kabupaten Karawang. Hal ini dapat diartikan bahwa semakin baik budaya organisasi maka akan meningkatkan kinerja mitra Dinas Koperasi dan UKM. Motivasi kerja secara parsial berpengaruh signifikan terhadap kinerja mitra Dinas Koperasi dan UKM Kabupaten Karawang. Hal ini dapat diartikan bahwa jika motivasi kerja mitra dapat ditingkatkan, maka akan mampu meningkatkan kinerja mitra Dinas Koperasi dan UKM Kabupaten Karawang. Lingkungan kerja secara parsial berpengaruh signifikan terhadap kinerja mitra Dinas Koperasi dan UKM Kabupaten Karawang. Hal ini dapat diartikan bahwa jika lingkungan kerja pada Dinas Koperasi dan UKM Kabupaten Karawang semakin baik, maka kinerja mitra Dinas Koperasi dan UKM Kabupaten Karawang akan meningkat. Budaya organisasi, motivasi dan lingkungan kerja berpengaruh secara simultan terhadap kinerja mitra Dinas Koperasi dan UKM Kabupaten Karawang. 


\section{Saran}

Secara praktis saran terhadap mitra, harus selalu berinovatif dalam menjalankan pekerjaan, karena dengan cara tersebut akan mampu menggali gagasan baru terhadap apa yang dikerjakan sehingga kejenuhan dalam bekerja tidak akan terjadi. Misalnya melakukan praktek langsung ketika memberikan pelatihan tentang laporan keuangan tidak hanya sekedar teori, mengadakan pertemuan bersama dengan bergantian tempat pada sesama pelaku UMKM pada saat pendampingan dan lain sebaginya. Mitra Dinas Koperasi dan UKM Kabupaten Karawang harus memiliki keberanian untuk menyampaikan pendapatnya kepada pimpinan, karena hal tersebut dilakukan untuk mengoptimalkan kerja sehingga apa yang ditugaskan akan terselesaikan dengan baik. Misalnya dengan cara menegur dan atau melakukan protes ketika ada intruksi yang kurang paham serta lain sebagainya. Untuk peningkatan kinerja, para mitra harus mampu meningkatkan kemandirian dalam mengerjakan tugas tanpa menunggu perintah dari pimpinan. Karena kemandirian terkait dengan kedewasaan atau tingkat kematangan seseorang (development) dalam bekerja. Semakin dewasa dan semakin tinggi posisi, orang seharusnya semakin mandiri dalam bekerja. Sebab semakin memahami bidang tugas, tingkat kemandirian kerja semakin tinggi. Dengan demikian, para mitra harus kembali memahami dan mengetahui pekerjaan nya masing-masing. Hal yang bisa dilakukan adalah mengadakan pelatihan tentang MSDM serta melakukan sertifikasi kompetensi kepada para Mitra.

Dinas Koperasi dan UKM Kabupaten Karawang perlu menyediakan sarana dan prasana yang mendukung semua aktivitas kegiatan pekerjaan agar para mitra bisa maksimal bekerja dengan baik. Hal ini bisa dilakukan dengan cara melakukan pengawasan atau kontrol terhadap sarana dan prasarana yang ada saat ini, serta melakukan perbaikan pada alat pendingin ruangan atau AC yang kurang berfungsi dengan baik di dalam ruangan. Karena bagaimanapun jika pendingan ruangan rusak, maka akan menyebabkan lingkungan kerja tidak nyaman.

Adanya kajian atau penelitian lebih lanjut tentang variabel lainnya yang mempengaruhi variabel kinerja mitra Dinas Koperasi dan UKM Kabupaten Karawang yang tidak diteliti dalam penelitian ini sehingga diharapkan kekurangan atau kelemahan terhadap mitra Dinas Koperasi dan UKM Kabupaten Karawang bisa diketahui secara menyeluruh. Saran Untuk Penelitian berikutnya adalah diharapkan hasil penelitian ini bisa digunakan sebagai bahan perbandingan dan referensi untuk penelitian dan sebagai bahan pertimbangan untuk lebih memperdalam temuan penelitian dengan mengunakan variabel-variabel peningkatan kinerja yang berbeda.

\section{DAFTAR PUSTAKA}

Ahmed, M., \& Shafiq, S. (2014). The Impact of Organizational Culture on Organizational Performance: A Case Study of Telecom Sector. Global Journal of Management and Business Research: A Administration and Management, 14(3), 975-985.

Akdon, dan Riduwan. 2013. Rumus dan Data Dalam Analisis Statistika. Bandung:Alfabeta.

Anwar Prabu Mangkunegara. 2009. Manajemen Sumber Daya Manusia Perusahaan. Remaja Rosdakarya, Bandung.

Bicho, P., Dias, D., Leite. A. \& Ramires, A. (2017). Working with cancer: motivation and job satisfaction. international journal 
of organizational analysis, 25(4), $662-$ 686.

Bushiri, C.P. (2014), The Impact of Working Environment on Employees Performance: The Case of Institute of Finance Management in Dar Es Salaam Region. Dissertation of Master in Human Resources Management. The Open University of Tanzania.

Chang, S. \& Lee, M. (2007). A study on relationship among leadership, organizational culture,the operation of learning organization and employees' job satisfaction. The Learning Organization, Vol. 14Iss 2 pp. 155 - 185 .

Czerw A.: Co ludzie myślą o pracy zawodowej? Konstrukcja metody diagnozującej postawy wobec pracy. Psychologia Społeczna, 2013, 8, 2(25):219-233

Fachreza, Musnadi, S., \& Majid, M. S. A. (2018). Pengaruh Motivasi Kerja, Lingkungan Kerja, Dan Budaya Organisasi Terhadap Kinerja Karyawan Dan Dampaknya Pada Kinerja Bank Aceh Syariah Di Kota Banda Aceh. Jurnal Magister Manajemen, 2(1), 1-8.

Ghozali, Imam. 2005. Aplikasi Analisis Multivariate dengan SPSS. Semarang: Badan Penerbit UNDIP.

Hamali, A. Y. 2018. Pemahaman Sumber Daya Manusia. Yogyakarta: PT Buku.

Hamdani, Z. (2017). Pengaruh Motivasi Kerja, Budaya Organisasi Dan Lingkungan Kerja Terhadap Kinerja Pegawai (Studi Pada Sekretariat Daerah Kabupaten Bireuen). Вестник Росздравнадзора, 18(2), 108-116.

Handayani, R.D. (2015), The influence of work motivation and work environment to the performance of library staff of ten November institute of technology (ITS) Surabaya. Journal of Public Administration and Bureaucracy, 8(5),
$35-42$.

Hasibuan, Malayu S.P. 2015. Manajemen Sumber Daya Manusia. Edisi Revisi. Jakarta: Bumi Aksara.

Indra Christina Marpaung. (2014). Budaya

Organisasi Dan Motivasi Kerja (Studi Korelasional Pengaruh Budaya Organisasi Terhadap Motivasi Kerja Karyawan di Seksi Smelter Reduction Operation PT Indonesia Asahan Aluminium, Kuala Tanjung, Batu Bara). Jurnal Ad'ministrare, 4(December), 43.

Jamaluddin, J., Salam, R., Yunus, H., \& Akib, H. (2017). Pengaruh Budaya Organisasi terhadap Kinerja Pegawai pada Dinas Pendidikan Provinsi Sulawesi Selatan. Jurnal Ad'ministrare, 4(1), 25. https://doi.org/10.26858/ja.v4i1.3443.

Jayaweera, T. (2015), Impact of work environmental factors on job performance, mediating role of work motivation: A study of hotel sector in England. International Journal of Business and Management, 10(3), 56-67.

Joushan, Shindie Aulia. (2015). Pengaruh Budaya Organisasi dan Keterikatan karyawan terhadap Kinerja Karyawan. Skripsi pada Departemen Manajemen Institut Pertanian Bogor. Bogor : tidak diterbitkan.

Kasmir. 2016. Manajemen Sumber Daya Manusia (Teori dan Praktik), Depok: PT. Rajagrafindo Persada.

Lestary, L., \& Harmon, H. (2018). Pengaruh Lingkungan Kerja Terhadap Kinerja Karyawan. Jurnal Riset Bisnis Dan Investasi, $3(2), \quad 94$. https://doi.org/10.35697/jrbi.v3i2.937.

Makuch M Reflections on work from the contemporary perspective society. Psychological and social approach. In: M. Makuch [ed.] The contemporary labor market. Employment and unemployment in the XXI century century. CEdu 
Publishing House, Wrocław 2014, pp. 3350

Mangkunegara, A. (2011), Human Resource Management Company. Bandung: PT Youth Rosdakarya. Riyanto, S. (2016), Selling Yourself: Menang Bersaing Di Era MEA. Jakarta: Kaifa, MarkPlus Inc

Maull, R., Brown, P., \& Cliffe, R. (2001). Organisational culture and quality improvement. International Journal of Operations \& Production Management.

Palvalin, Miikka. (2017). How to measure impacts of work environment changes on knowledge work productivity validation and improvement of the SmartWoW tool. Measuring Business Excellence, Vol. 21. Issue: 2,PP. -, doi: 10.1108/ MBE-05-2016-0025.

Peplińska, A., Godlewska-Werner, D., Celińska, S., Nieckarz, Z., \& Połomski, P. (2018). Przywiązanie do organizacji i motywacja do pracy a poziom materializmu pracownikówpośrednicząca rola satysfakcji z pracy. Zarządzanie Zasobami Ludzkimi, Various Approaches to Motivation or a New Look and Old Problems"), 11-30.

Rico Dio Alfonso. (2018). Analisis Korelasi Motivasi Kerja, Lingkungan Kerja, Dan Kinerja Karyawan Distributor Onderdil Sepeda Motor. AGORA, 6(2).

Riyanto, S., Adonia., Ali, H. (2017), Effect of motivation and job satisfaction on the performance of teachers in Mentari School Bintaro (MSB). International Journal: Scholars Bulletin, 3(3), 83-91. R. Supomo dan Eti Nurhayati. 2018. Manajemen Sumber Daya Manusia. Yrama Widya, Bandung.

Robbins, Stephen P. and Mary Coulter. 2012. Management, Eleventh Edition, (United States of America: Pearson Education Limited).

Sagita, A. A., Susilo, H., \& W.S, M. C.
(2018). Pengaruh Budaya Organisasi Terhadap Kinerja Karyawan Dengan Motivasi Kerja Sebagai Variabel Mediator (Studi Pada PT Astra Internasional, Tbk-Toyota (Auto2000) Cabang Sutoyo Malang) Alinvia. Jurnal Administrasi Bisnis (JAB)|Vol, 57(1).

Sarwani. (2016). The Effect Of Work Discipline And Work Environment On The Performance Of Employees. Jurnal Internasional Sinergi, 6(2), 53-67.

Sedarmayanti. 2013. Manajemen Sumber Daya Manusia : Reformasi Birokrasi dan Manajemen Pegawai Negri Sipil, PT. Refika Aditama, Bandung. .2012. Manajemen Sumber

Daya Manusia. Bandung: Refika Aditama.

Setiawan, Kiki, Cahaya., (2015). Pengaruh Motivasi Kerja Terhadap Kinerja Karyawan Level Pelaksana di Devisi Operasi PT. Pusri Palembang. Jurnal Psikologi Islami. 1 (2): 43-53.

Setyo, R., Adonia., Ali, H. (2017), Effect of motivation and job satisfaction on the performance of teachers in Mentari School Bintaro (MSB). International Journal: Scholars Bulletin, 3(3), 83-91.

Siregar, Sopyan.2012. Metode Penelitian Kuantitatif, Kencana, Jakarta.

Sofyan, D.K. (2013), The effect of work environment on BAPPEDA employee performance. Malikussaleh Industrial Engineering Journal, 2(1), 18-23

Stephen, E. N., \& Stephen, E. A. (2016). Organizational Culture and Its Impact on Employee Performance and Job Satisfaction: A Case Study of Niger Delta University, Amassoma. Higher Education of Social Science, 11(5), 3645. https://doi.org/10.3968/n.

Sugiyono. 2013, Metodelogi Penelitian Kuantitatif, Kualitatif Dan R\&D, Bandung: Alfabeta. 
.$\neg$ 2017. Metode Penelitian

Kuantitatif, Kualitatif, dan R\&D. Bandung: Alfabeta.

Supriyanto, H., \& Mukzam, M. D. (2018). Pengaruh Motivasi Kerja dan Lingkungan Kerja Terhadap Kinerja Karyawan ( Studi pada Karyawan LPP Radio Republik Indonesia Stasiun Malang). Jab, 58(1), 141-146. http://administrasibisnis.studentjournal.u b.ac.id/index.php/jab/article/download/2 $415 / 2810$.
Wambugu, L. W. (2014). Effects of Organizational Culture on Employee Performance (Case Study of Wartsila Kipevu Ii Power Plant). European Journal of Business and ManagementOnline), 6(32), 80-93. 